\title{
TURKEY'S RELATIONS WITH GERMANYFROM THE CONCLUSION OF THE MONTREUX STRAITS CONVENTION UP TO THE OUTBREAK OF THE SECOND WORLD WAR
}

\section{YÜCEL GÜÇLÜ}

Despite political controversies during the First World War, there had been little recrimination between Turkey and Germany after defeat in 1918. Whatever emotional hostility remained in both countries was directed against the victorious Allied powers which imposed humiliating peace terms upon the vanquished. Under these circumstances it was not difficult for the Weimar Republic to regain the friendship and confidence of Turkey.

The period between the conclusion of the Montreux Straits Convention of 20 July 1936 and the outbreak of the Second World War on 1 September 1939 witnessed some momentous developments in the position and policy of Turkey and in Turkish relations with Germany. Berlin was much displeased with the new regime of the Straits and looked unfavourably upon the possibility of Soviet naval forces in the Mediterranean. It was also disturbed by the ever-growing Anglo-French influence in Turkey, which might prove a limiting factor with respect to Nazi ambitions both in southeastern Europe and in the Middle East. Ankara viewed all these developments with a very cautious eye. It was especially concerned with events on the eve of the Second World War which pointed towards possible German and Italian domination over southeastern Europe down to the very borders of Turkeyl.

As in the First World War, the Straits area proved of considerable strategic importance on the eve of the Second World War, perhaps even a decisive part, in determining the course of events. For the Germans, in

${ }^{1}$ Montreux ve Savaş Öncesi Yilları: 1935-1939 (Montreux and Pre-War Years: 1935-1939), Publication of the Directorate General of Research and Policy Planning, Ministry of Foreign Affairs of the Republic of Turkey, Ankara, 1973, pp. 187 and 218-220. Tevfik Rüştü Aras, Görüşlerim (My Views), Istanbul, 1968, pp. 206-209. 
particular, it was important that, in any general war that might break out in Europe, Turkey should remain neutral and the Straits closed against the fleets of the Western powers. In the years preceding the outbreak of war in 1939, therefore, they were at pains to prevent Turkey joining one of the diplomatic combinations their principal enemies, Britain, France and Russia, were endeavouring to raise against them ${ }^{2}$.

After the signature of the Lausanne Peace Treaty of 24 July 1923, Germany along with its own economic recovery began to play a part of steadily increasing importance in Turkish trade. By 1924 German exports to Turkey were 27,4 million Turkish liras ( 13 percent of the total Turkish imports) as compared with 37,4 million TL. imported from Britain in the same year. By 1925 the Turks were already importing more from Germany than from Britain-31,6 million TL. from the former as compared with 27,4 million TL. from the latter. In 1930 Germany furnished 18,6 percent of Turkey's imports and took 13,1 percent of the exports; in 1932 the figures were 23 percent and 13 percent $^{3}$.

No effort was spared by Germany to win Turkish sympathies in every direction. German prestige had always been great in Turkey. By the Turkish producer, Germany had always been looked at as the generous buyer on whose decision it depended whether his crop would fetch a good price or not, and by the new class of Turkish merchants as the country with which it was both easy and profitable to do business. The supremacy of German trade in Turkey and the profit this brought to Turkish exporters and importers alike procured the Germans that kind of consideration which successful businessmen naturally enjoyed in the commercial world. In science and arts, too, the German government showed every determination to emphasise its achievements, vying in that respect with the Russians only. The basically revisionist character of German foreign policy did not quite comport with the Turkish devotion to the status quo, but, so long as Germany kept its hands off southeastern

2 Ibid.

${ }^{3}$ Documents on German Foreign Policy - henceforth referred to as D.G.F.P. -, ser. C, vol. 4, no. 26, Unsigned Memorandum, 12 April 1935. Also Cemil Koçak, Türk-Alman İlişkileri: 19231939 (Turco-German Relations: 1923-1939), Ankara, 1991, pp. 90-92 and Yahya Sezai Tezel, Cumhuriyet Döneminin İktisadî Tarihi: 1923-1950 (Economic History of the Republican Era: 1923-1950), Ankara, 1986, pp.144-145. 
Europe, Turkey had no particular cause for alarm. Certainly during the first decade of its establishment, Germany did not represent any kind of threat to the Republic of Turkey and the Turks were only too willing to enter into friendly relations with Berlin ${ }^{4}$.

The advent to power of Adolf Hitler on 30 January 1933 more or less corresponded with the launching of the first five-year plan for industry in Turkey. This was therefore an extremely propitious moment for Germany to begin to play a larger role in Turkish affairs than in the past. The Turks had been having great difficulties to place their raw products during the slump years, moreover Germany's position in Turkish imports had already been getting more and more important during the 1920s. The slump in the world market showed every sign of continuing and between the years of 1930 and 1933 Turkish exports even to Germany showed a considerable decline dropping from 19 million TL. in 1930 to 13 million TL. in 1932 and 1933. Turkey's chances of getting the necessary machinery and installations for its ambitious industrialisation plan were slender in the light of a considerably diminished export trade. It was here that Germany stepped in and offered a clear-cut solution, the political implications of which were by no means evident at the outse $t^{5}$.

When Hjalmar Schacht became the Minister of Economics on 2 August 1934, he almost immediately introduced the so-called "New Plan" for German economic ascendancy. By this system of accounts, foreign countries selling goods to Germany would have the amount of German purchases credited to their account in German currency and with this they could then buy anything they wanted in Germany. The advantage of this process from the point of view of Turkey as well as Germany was that it obviated the necessity of using scarce foreign exchange currencies to purchase commodities abroad. Turkey, anxious to sell its raw materials and agricultural products, Germany, happy to sell its finished products and not fall deeper into debt in terms of the international money market, regarded this barter scheme as a way of spending without $\operatorname{cost}^{6}$.

\footnotetext{
${ }^{4}$ Ibid. Koçak (1991), pp.55-56 and 86.

${ }^{5}$ Ibid. Koçak (1991), pp. 199-203. Tezel (1986), p. 154.

${ }^{6}$ Koçak (1991), pp. 199-200.
} 
In 1934 a German trade mission representing various Krupp's interests visited Turkey and had discussions with the Turkish government. The outcome was a long-term credit for 20 million TL. and also an agreement by the Turks to purchase a large quantity of railway materials and parts from Germany. The lively interest that the German government professed in the Turkish five-year plan and their willingness to assist in its realisation led to the sending in February 1935 of a German adviser to the Turkish Ministry of Economics. This official's job was specifically to assist with the getting under way of the five-year plan. In the same year the Turks ordered 11 million TL. of material from Krupp for the electrification of their railways ${ }^{7}$.

Two years of active German assistance in their economy had begun to raise political doubts at Ankara. Germany's Drang Nach Sudosten could be surveyed over a vast field of southeastern Europe and the Middle East. That it was a concrete plan with a political motive was blatantly obvious. But Turkish alarm at the beginning of 1936 was still largely one of possible Italian aggression in southwestern Anatolia. In eastern Mediterranean, Italy's presence in the Dodecanese islands, its intrigues with Turkey's neighbours as well as its avowed revisionism presented the most immediate threat. The German danger was already fully perceived later in 1936; but the economic results of trading with Germany had been rather fortunate for the Turks. The value of their exports to Germany had rocketed up from 19 million TL. in 1933 to 29 million in 1934 and to 35,5 in 1935. The peak was reached in 1936 with an export of 41,7 million TL. worth of goods to that country. It is true that the Turks were obliged to take repayment for this in the way Schacht thought best; but it so happened that munitions and the other productions of heavy industry that the Germans had available were just the materials that Turkey needed. The Schacht plan was in the first instance more successful in Turkey than in any other European country with the exception of Bulgaria. Within the short span of a few years Germany gained a dominant grip over Turkish economy and was well on the road to making continued economic assistance a lever to effect political ends ${ }^{8}$.

${ }^{7}$ D.G.F.P., ser.C, vol.4, no.26, Unsigned Memorandum, 12 April 1935. Koçak (1991), pp. 203-204.

${ }^{8}$ Ibid., ser. D, vol. 5, no. 535, Weizsacker to Keller (Ankara), 16 July 1937. Koçak (1991), pp. 209-217. Tezel (1986), p. 154. 
Meanwhile, President Kemal Atatürk was convinced that Germany would one day be the cause of another great war ${ }^{9}$. Atatürk described the German dictator as a tin-peddler, and as one of the few pre-1939 statesmen who had read Mein Kampf in its German edition, was horrified at the "meanness of the language and the madness of Hitler's thoughts"10. Nazi anti-Semitism, in particular, appears to have disgusted the Turkish leadership. Atatürk was so shocked by the treatment meted out to the Jews of Germany in the early 1930s that, by a curious route, he offered a home to them. His Jewish dentist Sami Günzberg spoke to him at great length about Hitler's anti-Semitism and the plight of the Jews in Germany. That information led him to consider the advantage to Turkey of giving asylum to some of Germany's gifted Jews who might help develop new Turkey. Many German Jews and other refugees from Hitler's persecution migrated to Turkey in the 1930s, including scholars and artists ${ }^{11}$. On 5 July 1934, the Prime Minister Ismet Inönü, was careful to stress to the Grand National Assembly that anti-Semitism was completely incompatible with Turkish nationalism ${ }^{12}$. The Führer was beyond the pale of Atatürk's aspirations as much as his actions. The latter believed that he had freed an enslaved people; the former was enslaving a free people and did not disguise the fact that he hoped to place others under Nazi yoke ${ }^{13}$.

The Turks considered that there would be no repetition of 1914. In May 1936, Atatürk told the British ambassador at Ankara Sir Percy Loraine: "There now seems to be the possibility, perhaps distant, perhaps not, of the German fact reappearing. The situation in that event would be uncomfortable and dangerous in the Turkish view: if it arose it would have to trim its course accordingly. At the moment it is resolved that Germany shall not again, as in 1914, have Turkey as the eastern pivot of its power."14

${ }^{9}$ Caucasus, 1, 1951, p. 16.

${ }^{10}$ Patrick Balfour Kinross, Atatürk: The Rebirth of a Nation, London, 1964, p. 460.

11 Vamı Volkan and Norman Izkowitz, The Immortal Atatürk: A Psycho-biography, Chicago, 1984, pp. 292-293.

12 Ísmet İnónü'nün TBMM ve CHP Kurultaylarında Söylev ve Demeçleri (1919-1946) [Ismet Inōnü's Speeches and Statements in the Turkish Grand National Assembly and in the Conventions of the Republican People's Party (1919-1946)], Istanbul, 1946, p. 280. Speech of 5 July 1934.

${ }^{13}$ Kinross (1964), p. 460.

${ }^{14}$ Foreign Office Papers, Public Record Office, London - henceforth referred to as "F.O." - 371/1011/63. Loraine (Ankara) to Eden, 8 May 1936. 
During 1936 Germany maintained its preponderating position in the economic life of Turkey-a position in which it took 49,5 percent of Turkey's exports and supplied 46 percent of Turkey's needs. This situation, though it assured Turkey a ready market, was not at all to the liking of the Turkish government. Germany was able to purchase Turkish staples on credit at a high price, and to retail them at a low price to other countries against cash in foreign exchange. On the other hand, the difficulty of paying high Turkish prices led the rest of the world to limit the scope of purchases from, and consequently of sales to, Turkey. Turkey was thus compelled to German goods at German prices, which, as a rule, were high. Large sums owing to Turkey were blocked in Germany, and it was therefore driven to take German goods on Germany's conditions. Apart from the fact that Turkey was economically isolated, and that it had thus come to finance German trade in Turkey, it could not ignore the fact that buying and selling at high prices was detrimental to its economic future. It would welcome a situation in which it was free to purchase elsewhere-particularly in Britain ${ }^{15}$.

Political relations between Turkey and Germany were correct but distant. Early in November 1936 it appeared that Turkey's friendship with the Soviet Union had engendered a certain hostility to Germany, which made Tevfik Rüştü Aras, the Turkish Foreign Minister, disinclined to overlook even trivial matters which could be construed as German slights to Turkey. The particular matter which gave rise to this observation was the visit of the Emden to Turkish waters for the purpose of transporting the German dead from Gelibolu to the summer residence of the German Embassy at Tarabya, where they were reinterred. Three facts had annoyed Aras. First, the Emden had visited Turkey after, and not before, visiting a Bulgarian port in the Black Sea; secondly, the German government had refused a Turkish offer to transport the dead themselves, with full military honours; thirdly, despite a clear hint, the captain of the Emden had invited the local authorities at Istanbul to a reception on the same day as a reception given by the Soviet consulate-general to celebrate the anniversary of the October revolution ${ }^{16}$.

15 Ibid., 20886/10426. Annual Report on Turkey, 1936. Para.s 119 and 120. Also Türkische Post, 1 November 1936. Moreover, see Koçak (1991) pp. 205-206 and 213-217.

${ }^{16}$ Ibid. 
Schacht visited Turkey, with great éclat, from 14 to 19 November 1936. He assured that Germany had not entered into any Mediterranean combination, and did not propose to do so. The Turkish government, on its part, explained that good relations with the Soviet Union were a necessity for Turkey, and that it would continue to cultivate them. It is possible that this discourse was provoked by soundings by Schacht on the question whether Turkey would join the German-Japanese front against the Comintern-a suggestion which was not encouraged. In the economic sphere, Schacht was reported to have proposed in the course of his visit that Germany should afford unlimited credits to Turkey for industrial development, repayment being effected by the surplus produce accruing therefrom, and to have met with a polite but firm refusal. At the same time the Turks did agree to examine a further proposal, i.e. that Germany should supply the plant, machinery, plans, etc. for the irrigation of the Adana plain for the purpose of cotton cultivation ${ }^{17}$.

Through the year 1936 Turkish statesmen began to take action to counteract the dangerous German monopoly. In June a three million pounds sterling contract for the erection of a new iron and steel works at Karabük, in spite of widespread rumours that Krupp would undertake it, went to the British company Brassert. The Turkish government was actively concerned over the country's dependence upon German economy, particularly in view of the cooling of Turco-German relations that took place during and after the conclusion of the Montreux Straits Convention ${ }^{18}$.

Germany, which was not represented at the Montreux conference on the Straits, reacted unfavourably to the new convention. The success of the conference, mainly due to the British concessions to the Soviet Union, and the détente which it produced were highly unwelcome to Germany. Attempts were made to belittle the importance of the convention and to dwell on the hope that the growing reservedness between Turkey and the Soviet Union would neutralise such gains as the latter had obtained. The German press was very hostile to the Montreux Convention and noted with

${ }^{17}$ Ibid. The Times, leading article, 16 November 1936.

${ }^{18}$ D.G.F.P., ser. C, vol. 5, no. 483, Keller (Ankara) to Foreign Ministry, 28 July 1936. For the text of the Montreux Straits Convention see League of Nations Treaty Series, no. 4015, vol. 173 (1936-1937), pp. 213-241. 
extreme disapproval Turkey's rapprochement with Britain. The Germans considered that the new Straits regulations increased the possibility of effective co-operation between the French and the Russians and they disapproved of its references to the League of Nations, Germany not being a member. On 26 February 1937 the German government gave practical expression to its dislike of the Montreux Convention by informing the Turkish government through diplomatic channels that certain shipping clauses in it were disapproved of strongly by the former and particularly those clauses which allowed the Soviet Union to send its warships into the Mediterranean ${ }^{19}$.

This high-handed approach received the sharp answer that the Turkish government, strengthened by the Montreux adjustment, now felt prepared to administer. The Germans were told that not being either signatories of Montreux or a Mediterranean power, the question of the Straits shipping was not a German matter, and that Turkey would brook no interference in issues vital to its security ${ }^{20}$. The Turks were not disposed to give great weight to the German reservations, warning that Germany was not free to pick and choose between the Montreux and Lausanne Straits Conventions-particularly as it was a signatory of neither. "If German reservations are maintained," Aras warned, the "German government would find itself confronted with a very positive Turkish counter-reservation": thus they would cease to enjoy the benefits of a signatory. Berlin left the problem at this point and agreed to regard the conversations as unofficial, realising that it was in no position to enforce its objections in practice ${ }^{21}$.

It was clear that Germany's concern was not in the field of legal rights, but in that of politics pure and simple. It was obviously an attempt to hit at the Russians, but in trying to hit the Russians, the Germans were bringing up the question of Turkish sovereignty. The Turks had agreed to give certain rights to war vessels of all countries, whether signatory to the

\footnotetext{
${ }^{19}$ Ibid., ser. D, vol. 5, no. 535, Weizsacker to Keller (Ankara), 16 July 1937. See also Survey of International Affairs - henceforth referred to as "S.I.A." - (1936), London, 1938, pp. 647-648.

${ }^{20}$ Ibid.

${ }^{21}$ F.O. 371/424/282. E1141/141/44. Loraine (Ankara) to Halifax, 22 February 1937. Ibid. E1198/141/44. Loraine (Ankara) to Eden, 24 February 1937. Ibid. E1202/141/44. Loraine (Ankara) to Eden, 24 February 1937.
} 
convention or not, but of course on the tacit assumption that these countries recognised Turkish sovereignty and the conditions laid down in the convention. If Germany for purely political reasons attacked the convention by putting on record a general reservation, then clearly Turkey was within its rights in closing the Straits to any German vessel.

Turkey had succeeded in becoming master of its own house, and patently was disinclined to countenance any schemes impinging on that mastery. It was a curious commentary on German psychology that , desperately anxious as the Berlin government had shown itself to reassert and to maintain national sovereignty, it should be so careless in its feeling for the susceptibilities of other nations equally concerned with national honour and integrity. Yet the situation needed care in its handling. TurcoGerman commercial relations were so important that tension in the diplomatic sphere might conceivably cause serious dislocation. Already Germany absorbed well over half Turkey's total exports; Turkey therefore was expected to do everything consonant with its dignity not to provoke its best customer. But interference with its plans of national security it plainly would not tolerate. Turkey adhered to no bloc but the bloc of peace. In that bloc, as far as it was concerned, was included the Soviet Union. And the fact that the Soviet Union was suspect in Germany's eyes was, in the Turkish view, unfortunate, but it could not be allowed to shape the schemes formulated by Turkey's integrity.

The growing reluctance of Turkey to follow any German lead was demonstrated in 1937 in several fields. Aras informed Loraine confidentially at the beginning of 1937 that he had received a personal invitation from Hitler to send a Turkish warship or squadron to visit a German port, in order that the occasion might be used for a grandiose manifestation of Turco-German friendship. Aras said that the Turkish government did not propose to accept. Also an awkward incident threatened at one moment during 1937 seriously to disturb Turco-German relations. A driver of the German embassy had knocked down and severely injured a pedestrian with his car. He was brought to trial, convicted and sentenced to a short term of imprisonment, but the Turkish authorities were unable to carry the sentence into effect, since the German ambassador refused to release the man from the German embassy. The Turkish government took a serious view of the matter, considering that the 
German embassy was wilfully thwarting the ends of justice. Eventually the German government gave in, apparently at the instigation of Hitler himself, and the driver was handed over to the Turkish authorities. The Turks had thus been successful in obtaining a settlement on the only lines acceptable to them. Aras had kept Loraine informed of the progress of the case, and at one moment told him that in the event of a rupture in diplomatic relations it was proposed to ask the British government to take charge of Turkish interests in Germany ${ }^{22}$.

In the economic sphere, there were evident signs of a growing determination on the part of the Turks to free themselves from the economic strangle-hold which Germany, with some success, had attempted to impose on Turkey in common with other Near Eastern and Balkan countries of recent years. The Turco-German Commercial and Clearing Agreements were denounced by Turkey in the early part of 1937. A Turkish delegation went to Berlin in the summer and signed a new agreement on 30 August, which came into force on 15 September for a duration of eleven and half months. The new agreement reflected Turkey's determination to eliminate its adverse trade balance with Germany; the Turkish delegation had received instructions that annual Turkish exports to Germany should be limited to fixed figure, for the virtual monopolising of the Turkish export market by Germany had meant that Turkish money was blocked in Germany and payments to Turkey were in effect made in "monnaie de singe"23.

The genuine attempts of Ankara to create unity in the Balkans indicated that Turkey recognised Germany as a growing menace in the heart of Europe with dreams touching the Turkish frontiers. Turkey was less exposed to the German threat than other Balkan countries, but it had realised that unless a halt was called sooner or later it might feel its effects. Germany intended to tear down the existing structure of Central Europe. This meant jeopardising peace, held so dear by Turkey. Here Turkey and Germany were inevitably opposed to each other. Germany wanted to play off the various Balkan aspirations. Turkey desired such a union since it welcomed every move towards regionalism contributing to the stabilisation of Europe.

22 Ibid., 21935/10426. Annual Report on Turkey, 1937. Para. 77.

${ }^{23}$ Ibid., Para. 78. Koçak (1991), pp.206-208 and 217-219. Tezel (1986), pp. 154-155. 
The relative uneasiness of Turco-German political relations came gradually as a result of the formation of the Rome-Berlin Axis on 1 November 1936. Hitler and Benito Mussolini formally agreed that the Mediterranean should be regarded as an Italian sphere of influence. Germany reiterated its disinterest in the Mediterranean and its support for a strong Italian position in the area. Hitler considered the Mediterranean as an Italian sea in which Italy had the right to exercise a dominant role. During Mussolini's visit to Germany in September 1937, it was agreed that Germany would continue to support Italian interests in the Mediterranean, while Italy would recognise Germany's supremacy in Central Europe ${ }^{24}$.

Implicit German support of Italian claims underlined the difference between Turkish and German objectives. By its participation in the Nyon conference of 14 September 1937, on the policing of the Mediterranean during the Spanish civil war, Turkey stressed its interest in preserving the status quo and the principle of collective security, both features unpleasant to Germany. The Turkish government hence viewed German policies with growing alarm, first because of the latter's close relations with Italy and, second, on their own account. The intense diplomatic activity of the tireless Aras during 1937; his visits to diverse European capitals, his attempts to keep Balkan countries in line, and lastly the Saadabad Pact, were all manifestations of the concern with which Turkey regarded the growing menace of Germany. Taken with the Wilhelmstrasse's economic policy, political developments made it obvious to Turkey's statesmen, by the end of 1937, that Germany was once again looking southeast with greedy eyes ${ }^{25}$.

Nevertheless Turkish diplomacy was not willing to swivel its affections too far towards one faction. The quarrels with Germany were not allowed to develop into too serious proportions. Krupp had failed to get the contract for rearmament of the Straits though this company had offered a very cheap estimate for the work; yet the trade volume-of such fundamental importance was it to Turkey-remained at a peak level. On the other hand, a contract signed in mid-February 1937 with the same

24 Galeazzo Ciano, Ciano's Diplomatic Papers, Edited by Malcolm Muggeridge, London, 1948, pp. 44 and 278.

25 Ismet Inōnū, Turkey: Ten Eventful Years: 1938-1947, New York, 1948, pp. 3-4. 
Krupp provided for the supply of ten vessels, whose size varied between 1.000 and 5.000 tons. A German firm, too, was building four submarines for Turkey. That these orders were placed with German firms was mainly due to the fact that Germany owed Turkey about five million pounds sterling in respect of Turkish products, and Turkey was, consequently, anxious to purchase from it whatever it could ${ }^{26}$.

Turkey's attitude towards Germany remained correct, but rather unenthusiastic and distinctly wary, and received further definition in the course of 1938. On his appointment as Foreign Minister, Joachim Von Ribbentrop addressed an enquiry to Aras respecting Turkish views on the relations between the two countries. Aras informed Loraine that his reply had been to the effect that Turkey enjoyed the friendliest relations both with the Soviet Union and Britain, and that it would be utterly impossible for it to belong to any combination or take any engagement which might conceivably prejudice either of these powers: that Turkey was bound by the Balkan Entente and by the Saadabad Pact, would fulfil its obligations under these instruments and could not consider realigning its policy or accepting fresh engagements unless in consultation and agreement with both sets of partners: but that within this framework German friendship would be welcomed and Germany could be assured that Turkey would not enter any combination directed against it. And Aras enquired whether, in these circumstances, Turco-German friendship could continue on its existing bases. Von Ribbentrop's answer was to the effect that he now understood the Turkish position-which, indeed, Aras' communication had made abundantly plain-but that he might wish to revert to the matter again. Aras later amplified this statement of the Turkish attitude by saying that Turkey did not wish to see Germany either on the Black Sea or on the Aegean; it was resolved-and in this resolve the other Balkan states were with it-firmly to resist the "Drang Nach Osten". In the Near East, Turkey was the first and the greatest obstacle of any such German dream. If Ankara chose to enter into commercial undertakings with Berlin it was certainly with no blind eye upon all possible implications ${ }^{27}$.

${ }^{26}$ Edward Vere-Hodge, Turkish Foreign Policy: 1918-1948, Anne-Masse, 1950, pp. 113-114. Koçak (1991), pp. 205-207.

${ }^{27}$ F.O. 371/23301/10426. Annual Report on Turkey, 1938. Para. 89. 
In the political field one question at issue between Turkey and Germany throughout 1938 was that of Berlin's position in regard to the agreement on the Turkish Straits. Since Germany had not been a signatory of the Lausanne Treaty it had not been invited to sign the Montreux Convention, and had subsequently notified Turkey that it reserved its freedom of action as regards the new regulations. In July 1937, after Germany's right to increase its naval strength had been recognised by Britain, Berlin became desirous of reaching an agreement with Turkey by which it would be granted the rights enjoyed by signatories of the Montreux Convention and would receive an assurance that it would be invited to participate in any revision of the regulations. At the same time Germany claimed that, as a state that was not a member of the League of Nations, it would be allowed to reserve its position concerning the provision in the Montreux Convention that, in the event of a war in which Turkey was not a belligerent, warships would not be permitted to pass through the Straits in either direction except in fulfilment of obligations under the League Covenant, or to render assistance to a victim of aggression in virtue of a treaty of mutual assistance binding on Turkey and concluded within the framework of the Covenant. Turkey was reluctant to conclude a bilateral agreement on these lines with Germany-it was no doubt apprehensive, in particular, of the effect of such a move on its relations with the Soviet Union-and it dealt with the problem by conducting the diplomatic exchanges on it in a cautious manner ${ }^{28}$.

The Turkish government gave Germany confidential verbal assurances that they would never enter into a treaty of mutual assistance which would make it obligatory to them to allow the passage of warships to assist a victim of aggression; and they also promised that as soon as an opportunity for revising the Montreux Convention should arise, Turkey would make it its business to see that Germany was included among the participants in the conference ${ }^{29}$.

It is to be noted here that Italy had refused to participate in the Montreux conference on account of the attitude taken by the League of Nations to Italian aggression against Ethiopia. The question of Italy's

${ }^{28}$ D.G.F.P., ser. D, vol. 5, no. 548 and fn. 2, Memorandum by Ribbentrop, 7 July 1938.

${ }^{29}$ Ibid., no. 550, Circular to all the principal diplomatic missions, 16 August 1938. 
accession to the Montreux Convention had been under discussion between the German and Italian governments in the spring of 1937, and it had been agreed that the two governments should consult before taking any definite step in the matter. Germany gave its consent on 26 April 1938 to Italy's accession to the convention ${ }^{30}$.

Meanwhile the Turkish government accepted an invitation, given shortly after the annexation of Austria to Germany on 12 March 1938, to send a delegation to Berlin for negotiations on the question of including Austria within the scope of the Turco-German economic agreement. The existing agreement was due to expire on 31 August 1938, and at the suggestion of the Turks it was decided that the negotiations should have as their object the conclusion of a new agreement to remain in force until August 1939. The negotiations began at the end of June, and the Turkish delegation showed themselves ready and even anxious to arrange for a considerable increase in reciprocal trade. In the agreement which was signed on 25 July Turkey made an important concession to German wishes by guaranteeing that Turkish deliveries of ores and wheat should be at least as large as $1937^{31}$.

The wider question of the basic principles of Turkish foreign policy and their application to Turco-German relations was discussed on three occasions during 1938 between the Turkish representatives and Ribbentrop. On 5 April the suave Turkish ambassador in Berlin, Hamdi Arpağ, told Ribbentrop that Turkey's position was one of conciliation and neutrality towards all sides; that it was trying to keep out of any coalitions, and had rejected a Soviet proposal for the conclusion of a mutual assistance pact; and that a visit from Ribbentrop would be welcomed in Turkey. Ribbentrop neither refused nor accepted this invitation, but left the possibility open for the future ${ }^{32}$.

In regard to Turkey, Germany was already in open competition for influence with Britain and France. The strategic position of the country

\footnotetext{
${ }^{30}$ Ibid., no. 535, Weizsacker to Keller (Ankara), 16 July 1937. Ibid., no. 543, Foreign Ministry to Mackensen (Rome), 29 April 1938.

31 Ibid., no. 545, Memorandum by Clodius (Deputy Director of the Economic Policy Department), 29 June 1938. Ibid., no. 546, Memorandum by Clodius, 5 July 1938. Ibid., no. 547. Memorandum by Clodius, 6 July 1938. Ibid., no. 549, Memorandum by Clodius, 8 August 1938.

${ }^{32}$ Ibid., no. 542, Memorandum by Ribbentrop, 5 April 1938.
} 
which controlled the Straits made it an eagerly sought associate, Turkey's desirability as a friend being further enhanced by its importance as a source of chrome ore. In the economic field, Germany had been trying to regain the strong position it once held in Turkey's internal economy and foreign trade with notable success before 1937. When German imports from Turkey had built up too large a clearing balance in favour of the latter, Berlin placed restrictions on them so that by the spring of 1938 a rough balance had been reached between Germany's exports of industrial goods and weapons for imports primarily of chrome ore, wheat, and tobacco. Almost half of Turkey's foreign trade was with Germany, and the political as well as economic significance of this tie was underlined by the sending of the Secretary-General of the Turkish Ministry of Foreign Affairs, Numan Menemencioglu, to Berlin in the summer of 1938 for the negotiation of a new trade agreement.

During the greater part of July 1938 the critically important Menemencioğlu was in Berlin as head of the Turkish delegation engaged in economic negotiations, and the fact that he had been nominated to this post was taken in Berlin as a sign that Turkey was willing to enter into general political conversations. In two interviews between Menemencioğlu and Ribbentrop on 1 and 7 July the latter made unavailing efforts to draw Turkey into closer association with Germany. In the first interview Menemencioğlu declared that Turkey did not intend to enter any coalition directed against Germany, and suggested that Turco-German relations should be based on the principle of benevolent neutrality. Ribbentrop agreed that this would afford a basis on which closer cooperation could be developed and went on to reveal his ignorance of the spirit that had inspired the Turkish National Revolution by suggesting that if the states which had suffered under the peace settlement were to align themselves diplomatically they would be in a stronger position to secure revision of the peace treaties ${ }^{33}$.

Menemencioğlu's reply, given during this second interview, was that Turkey was not interested in treaty revision; what it wanted was to accomplish its internal reconstruction in peace; and for that purpose it considered that neutrality was its best policy. Ribbentrop then took the

${ }^{33}$ Ibid., no. 548, Memorandum by Ribbentrop, 7 July 1938. 
line that, if the difficulty about the Montreux Convention could be got over, Turco-German relations might be reformulated on a basis of neutrality, but he asked for a definite promise that Turkey would not enter into any combination directed against other countries. His idea was, apparently, that a Turco-German treaty should be signed on the pattern of the Turco-French Treaty of Friendship of 4 July 1938. Menemencioğlu replied that Turkey would prefer its relations with Britain to be the model: that is, no formal agreement, but a mutual understanding that neutrality could be taken for granted. Menemencioğlu's attitude drew from Ribbentrop the question whether Turkey had promised the Soviet Union not to conclude a treaty of neutrality with Germany, and Menemencioğlu denied that there was any truth in this suggestion ${ }^{34}$.

The upshot of the conversation was summed up in a circular from the German Foreign Ministry to diplomatic missions on 10 August in the phrase: "Turco-German relations are unchanged, but Turkey still hesitates to give them a new and more intimate form, at least at the present time." The circular also mentioned that Menemencioğlu had promised that the latest German draft of an exchange of notes on the Straits question would be examined, and had declared that the recent Turco-French Treaty of Friendship had not brought about any change in the traditional Turkish policy of neutrality, especially with regard to Germany ${ }^{35}$.

Selim Deringil mentions that Menemencioğlu and his policies have been the subject of much controversy. Deringil goes on to state that to some Menemencioğlu was decidedly pro-German and favoured closer cooperation with Berlin. To others he was first and foremost Turkish, and as such entirely ready to be completely pragmatic in taking care of what he considered to be Turkey's vital interests ${ }^{36}$. It was this pragmatism which

${ }^{34}$ Ibid. Similar assurances were given to the German ambassador in Ankara on 10 July 1938, when he questioned the Turkish Foreign Minister on the significance of the recent TurcoFrench treaty. See ibid., no. 211 and fn. 2, Memorandum by Weizsacker, 14 July 1938 . On this occasion, Aras stated that the treaty with France did not go any further than the usual treaties of this kind but that it would be entirely unnecessary to conclude a similar treaty between Turkey and Germany; he declared emphatically that Turkey would never participate in diplomatic combinations directed against Germany.

${ }^{35}$ Ibid., no. 550, Circular to all the principal diplomatic missions, 16 August 1938.

${ }^{36}$ Selim Deringil, Turkish Foreign Policy During the Second World War, Cambridge, 1989, p.52. 
led to his coming to be seen as 'pro-German' in some circles. According to the French ambassador at Ankara between the years of 1939 and 1940, René Massigli, Menemencioğlu had the reputation of being a Germanophile, especially in Berlin ${ }^{37}$. The noted German historian Gerhard Weinberg also points out that Menemencioğlu was believed in Berlin to be a leader of the pro-German party in the Turkish government ${ }^{38}$. But those who gave him this reputation grossly mistook him. He was, above all, a Turk and essentially a realist in international politics. Sentiment or sympathy was not a valid criterion where his judgements were concerned. He based his decisions on frank calculations of enlightened self-interest and he generally assumed that others would follow the same principle. He did not conduct foreign policy from any determined ideological theories, but according to the dictates of geography and the needs of the time.

Although Menemencioğlu might have admired the economic and military efficiency of Germany, he was deeply distrustful of Germany's motives. He was apprehensive of unchecked ambitions of Germany, as he felt anxiety over such designs on the part of the Soviet Union. Thus Britain's ambassador to Turkey in 1939-1940, Sir Hugh KnatchbullHugessen, would state that Menemencioğlu was not pro-German and he was convinced that the Turkish diplomat was activated by his conceptions of his country's interests and not by any predisposition to favour Germany. In other words, Menemencioğlu, being an able and professional diplomat, was only doing the best for his country ${ }^{39}$.

During the next six months the German government made no further direct attempt to establish closer political relations with Turkey, but followed the policy of building up economic relations as a basis for a later advance in the political field. In their credit agreement with Britain of 16 May 1938 the Turks had entered into a definite commitment to deliver raw materials equivalent in value to the amount of credit granted, and the Germans had made it the central point of the negotiations that they

\footnotetext{
${ }^{37}$ René Massigli, La Turquie devant la Guerre: Mission à Ankara 1939-1940, Paris, 1964, p.77.

${ }^{38}$ Gerhard Weinberg. The Foreign Policy of Hitler's Germany: 1937-1939, Chicago, 1980, p. 241.

${ }^{39}$ Deringil (1989), pp. 53 and 55-56.
} 
should receive no less favourable treatment in this respect than Britain. The head of the Turkish delegation not only declared that the credit agreement with Britain was not intended to reduce Turco-German trade but said that for political purposes the Turkish government would be glad at any time to conclude a similar agreement with Germany ${ }^{40}$.

The Germans took the opening thus offered them, and an agreement for a ten-year credit of 150 million German marks was negotiated on 6-8 October 1938, when Walter Funk, German Minister of Economics, visited Ankara, the proceeds to be applied to the purchase of armaments and equipment for industrial and public works. At the beginning of September 1938 Funk had called attention to the importance of offering the German credit in advance of a projected visit from the French Foreign Minister, Georges Bonnet, to Ankara, since it was believed that the French intended to offer credits to Turkey in order to undermine Germany's economic position there. In the event, the visit of the French Foreign Minister did not take place. According to the terms of the credit agreement, which was signed in Berlin on 16 January 1939, the Turkish government was to pay interest at the rate of five percent and to reimburse the credits granted within ten years from the date of incurring liability. Except in matters of detail, the agreement appeared to follow very closely the lines of the earlier credit agreement with the British government which had provoked so much hostile criticism in Germany ${ }^{41}$.

Turkish development policy, the collapse of equitable international exchange attendant upon the Great Depression, and the policies of Schacht, had combined to produce an economic situation inimical to Turkish economic independence and which made Turkey economically reliant on Germany. Schacht's "New Plan" involved the creation, after 1933, of a web of bilateral barter arrangements with the nations of southeast Europe by which Germany would obtain crucial raw materials in exchange for manufactured articles. The arrangements worked better than Schacht could have hoped or the Balkan partners wanted and quickly led

${ }^{40}$ D.G.F.P., ser. D, vol.5 no. 552, Wiehl (Director of the Economic Policy Department) to Keller (Ankara), 15 September 1938. Ibid., no. 554, Clodius to Keller (Ankara), 4 October 1938. Ibid., no. 557, Memorandum by Moraht (Head of Economic Policy Division III), 20 January 1939. Koçak (1991), pp. 232-235.

${ }^{41}$ Ibid. Koçak (1991), pp.236-239. 
to something like German economic dominance of the region. In 1931, Germany received 10,7 percent of Turkish exports and supplied 21,3 percent of its imports. By 1936, Germany was receiving 51 percent of Turkish exports, and supplying 45,1 percent of its imports. By September 1935, Germany was receiving 83 percent of its import requirements by barter $^{42}$.

Briefly stated, the elements of Turkish dependence were as follows:.

1. Like most developing countries, Turkey had redirected its agriculture away from the satisfaction of needs and towards the production of materials internationally marketable. Schacht's policies made the Germans much the most important customers of Turkey. The first result of any move towards conflict with Germany, then, would be the collapse of a trade which had become crucial to Turkey's political and economic well-being. In this way, while German dependence upon certain Turkish exports placed a weapon in Allied hands, the German market, in itself, constituted a powerful counter weapon. This was most especially the case since Turkey's trade had been ravaged by the Great Depression. In 1929, Turkey in total had imported 256 million TL. of material with exports valued at 155 million TL. By 1933, imports had declined in value to 74,6 million TL. and exports to 96,2 million. Recovery thereafter was fueled almost entirely by trade with Germany while trade with other Western countries continued to languish ${ }^{43}$.

2. A Turkish embargo might hurt the Germans, but the Turkish producers would face disaster. Since the Turkish government marketed most Turkish products through a system of state monopolies the damage would be three-fold: the producers themselves would lose their most important market; the government would lose a large part of its revenue; and the products which the government purchased from the Germans with the profits from the monopolies would no longer be available. The most extreme case of such dislocation would be in Turkey's nascent

42 See Hjalmar Schacht, The Old Wizard, Boston, 1956, pp. 304-340. Also Oya Köymen and Atilla Sönmez, "The Social and Economic Background to Turkey's Noninvolvement in the Second World War", Studia Balcanica, 7, 1973, passim.

43 United Nations Statistical Office, Year Book of International Trade Statistics, New York, 1950, p. 149. See also Berç Berberoğlu, Turkey in Crisis: The Transition from State Capitalism to Neo-Colonialism, London, 1982, pp. $47-48$. 
metallurgical industry. Chrome mining, for instance, was at once Turkey's most strategically important, and most quickly burgeoning industry. It was also a profitable government monopoly, one of those least likely to be able to redirect its production towards politically more congenial markets ${ }^{44}$. It was also the industry to which Turkey looked to provide the engine of its development programmes ${ }^{45}$.

3. Germany's half of the trade consisted of manufactured and semimanufactured goods essential for the middle-term functioning of the Turkish economy. The second result of trade embargo would be the virtual collapse of the manufacturing sector of the Turkish economy as technical help was withdrawn, spare parts ran out, and the railways ceased to function. In this sense, factories built by the Germans for the Turks in their drive towards economic autonomy would be only so many hostages, and would not increase-as had been intended-but decrease Turkey's political flexibility.

4. Finally, since the Turkish army obtained many of its armaments and all of the machinery for its arms factories from Germany, in the event of breach of relations, it would soon be unable either to service the arms it had or to feed those still functional. Thus, Turkey's ability to defend itself would decline absolutely. In this sense, every German weapon placed in Turkish hands made it less likely that Turkey would ever be able to turn against Germany.

This was not a condition peculiar to Turkey, but one Germany shared with all Balkan countries. Like the others, by 1937, Turkey was looking for ways to escape from this dangerous dependency upon a country whose foreign policy goals were becoming increasingly inimical to Turkey's own. The search gained urgency as the desire to oppose German political expansion in the Balkans grew-hardly an option while Turkey was dependent upon Germany for its economic existence. Unless this could be changed, the economic limitation would continue to be political

${ }^{44}$ Bulletin of International Affairs, vol. 15, no. 8, 23 April 1938, p. 7.

45 Celal Bayar, "Ekonomi Bakanı Celal Bayar'ın İlk Beş Yıllık Sanayi Programı Hakkında Gazetecilere Demeci" ("Press Statement of Celal Bayar, the Minister of Economics, on the First Five-Year Industrial Programme"), Celal Bayar'ın TBMM'de Yapuğı Kanun Tekliflerinin Esbabı Mucibeleri (Reasons for the Bills Proposed by Celal Bayar in the Turkish Grand National Assembly), Edited by Özel Şahingiray, Ankara, 1955, pp. 92-94. 
limitation as well. Şükrü Saraçoğlu, the canny Foreign Minister, described this stark economic reality and its connection to political choice in December 1939: "There is still another truth which requires that, in order that a country may have an independent national policy, the greater part of its foreign trade must not be directed towards a single country. To however small an extent foreign trade becomes the monopoly of a single country, it is very difficult to pursue an independent national policy, even if this country should be an ally. When national policy, the aim of which is independence, and national trade, the object of which is profit, can no longer go side by side, national trade must make a sacrifice." ${ }^{46}$.

It was through better economic relations with Britain, France and the United States that Turkey sought political independence. Unfortunately for Turkey, Western economic policy in the years prior to the Second World War did not combat the growth of German influence, but underwrote it. The crux of the problem was exchange. The fact was that the products that Turkey had for sale were widely available, and worse, in the British case, were available from countries benefiting from imperial preference. Tobacco, for instance, a high value product which Turkey had in large quantity, had no British market after the First World War. Figs, raisins, and nuts-other major Turkish cash crops-either had little British market, or were available from Australia which regarded its British market with a jealous eye. Turkey simply could not sell in Britain products of sufficient value to obtain goods it would need if German trade were to be reduced $^{47}$.

In the French case, it was not that Turkey had trouble selling in France, but that French quotas artificially restricted trade. By 1936, the Turks were complaining that trade with France was rapidly collapsing to the benefit of Germany which took up the slack ${ }^{48}$.

The natural outcome of Western reluctance to buy Turkish produce was to drive down the value of the Turkish lira, which in turn, made Western manufactured articles much more costly than would normally have been the case. And the natural result of this, of course, was to

\footnotetext{
${ }^{46}$ Anatolian News Agency, 14 December 1939.

${ }^{47}$ F.O. 371/1011/39. Loraine (Ankara) to Oliphant, 13 March 1936.

48 Ibid. Account of the conversation with Şükrü Saraçoğlu, Fethi Okyar and Faik Kurtoğlu.
} 
reinforce German trade which was orchestrated by Berlin with an eye to political as much as financial advantage ${ }^{49}$.

This was only part of a long and sorry story. Turkey's trade with Britain and France was hobbled also by Western, particularly French, insistence that Turkey service its portion of the Ottoman debt. By the Treaty of Lausanne, debt payment recommenced in 1931 and soon came to consume 13-18 percent of the Turkish budget. What did this mean? Turkey traded with the West to obtain Western currencies, but then used these to meet debt coupons rather than to buy Western manufactures. The non-productive trade in currencies, of course, further depressed the price obtainable for Turkish produce by deflating the lira and priced Western manufactures still higher by inflating Western currencies. In Germany, Schacht's unorthodox economic arrangements had resulted in an abnormal demand for Turkish goods and in prices far above world prices; in some cases, as much as twice the world price. The end result was that the trade of other countries was crowded out, and German domination of Turkish markets cemented almost beyond correction ${ }^{50}$.

Germany's efforts to ensnare Turkey within the Nazi orbit had not been limited to commerce, though this had been the over-ridingly important contact between the two countries. A certain amount of initiative had also been expended on cultural propaganda. Financial backing was given to books that stressed Turco-German amity and a German newspaper Türkische Post, received backing for propagating the German viewpoint. In addition special facilities were made to attract Turkish students to complete their studies in German universities and technical colleges. Particularly by instructing young Turkish technicians, Germany hoped to form a German-trained personnel who on their return to Turkey would fill key governmental posts, and whose corporate proGerman influence would have a decisive effect upon Turco-German relations $s^{51}$.

Turkey wished to develop its economic relations with Britain, France and the United States since the early 1930s. But the Western economic

\footnotetext{
${ }^{49}$ Berberoğlu (1982), p. 33.

${ }^{50}$ Ibid.

${ }^{51}$ Vere-Hodge (1950), p. 114.
} 
policy in the 1930s did not accommodate with that of Turkey's financial position. The West and, Britain in particular, was unwilling to provide loans and credits of any kind for any purpose. Economic assistance was hampered by strenous Treasury insistence that Britain's economic resources were limited, and that provision had to be made for many projects of higher priority before much could be done for Turkey. Despite Britain's desire to draw Turkey to its side following the Italian occupation of Ethiopia, the former's refusal to supply credit to the latter until 1938 and its reluctance to increase Anglo-Turkish trade at the expense of the Dominions indicate that Whitehall in fact considered Ankara important not from an economic but from a strategic angle.

The policy of ambivalent and ambiguous friendships was already forming in Turkish minds in 1938 as the array for a further world conflict began to take shape. Germany and German trade were far too useful for Turkey to consider any serious rupture with that power. On the other hand, firm British support as protection in the Mediterranean was essential. Turkey ardently desired to preserve a double friendship and to balance itself as mistress of the Straits between the rival aims of Germany and Britain, even in the very same way as through centuries of history it had balanced its diplomacy between the interests of Russia and Britain ${ }^{52}$.

With this aim in view German overtures, though regarded with high suspicion, were not all rejected. Thus on 21 April 1939 a German industrial consortium-Gutehoffnung Shutte, Philippe Holzmann, Julius Berger and Siemens Bav-Union-was called in to build the naval base and arsenal at Gölcük in the Gulf of Izmit. The contract was not a small one. It was valued at 2,3 million pounds sterling in Europe and 150 million TL. in Turkey over four years. It was also accorded substantial political weight. In diverse ways the Germans showed their ever increasing interest in Turkey as the springboard to the Middle East. An air service between Turkey and Germany was inaugurated; Berlin radio began transmissions in Turkish. All and everything was done by the Germans to bring Turkey within the German sphere of influence ${ }^{53}$.

52 Ibid.

53 D.G.F.P., ser. D, vol. 6, no. 413, Memorandum by Papen and fn. 6, 20 May 1939. See also F.O. 371/23297. E4107/272/44. Knatchbull-Hugessen (Ankara) to Halifax, 27 May 1939. 
In fact, for a long time Germany had been endeavouring to enlist Turkey on its side, but its efforts were in vain. Atatürk had never belonged to the narrow political clique which brought the Ottoman Empire to the side of the Central Powers during the First World War. Moreover, the head of state and most of his closest associates in the government were former Ottoman army officers who had bitter experiences with their wartime comrade-in-arms and therefore they had neither natural sympathy nor any kind of inclination towards Berlin whose old dreams of expansion across the Asia Minor, since the advent to power of Hitler, it was felt to be reviving. Turkish leadership had also never forgotten that the downfall of the Ottoman Empire resulted from alliance with Germans. Their wartime experiences had taught the Turkish leaders to resent the German influence over Turkey and to oppose the domination of any foreign power. It is both interesting and significant that as the First World War approached, Atatürk had argued strongly against the Ottoman Empire's participation alongside Germany, as he had not been sure that the Germans would be able to win and he had not trusted their intentions. Turkey had experienced a German alliance and it wanted no repetition of that.

At this point it should be stressed conversely that Berlin's intention to destroy the existing political structure in the Balkans, contrary to the Turkish policy of keeping the status quo in that area, and the collaboration between Germany and Italy - Turkey's potential enemy over the Balkans and the eastern Mediterranean, prevented Germany in practical terms to come closer to Turkey for political and military cooperation. Remarkably, Franz Weber goes much further and suggests that in 1938 Germany was unwilling to accept a partnership with Turkey. The American scholar, using German records, asserts that some German statesmen valued an arrangement with the Arabs over an alliance with Turkey, while others strove for an untroubled relationship with the Soviet Union that would postpone the threat of war on the eastern front when fighting broke out in the West. They did not want to conspire with Turkey, Russia's ancient foe ${ }^{54}$. Nevertheless, one may argue that on only one

\footnotetext{
${ }^{54}$ Franz Weber, The Evasive Neutral: Germany, Britain and the Quest for a Turkish Alliance in the Second World War, Missouri: St. Louis, 1979, pp.2-3.
} 
subject was Germany clear in its perception of policy towards Turkey: it desired to insure Turkish neutrality in a future European conflict.

The competition for Turkey's favour would continue after Munich; but in spite of pleasantries and assurances, Germany did not obtain the political guarantees of Turkish neutrality in case of war that it very much wanted to secure. On the other hand, the Turkish government had been careful - and would continue to be careful - not to become involved in any arrangement pointed against Germany. Ankara was trying hard to keep the country out of any possible involvement in war; and since this was really what Germany also wanted of Turkey at that time, the stand-off on the Bosphorus could hardly be said to be damaging to German policy objectives.

The Munich agreement of 30 September 1938 over the dismemberment of Czechoslovakia gave Turkey new concern since it illustrated the close collaboration between the European dictators. The occupation of the rump state of Czechoslovakia on 15 March 1939 made it clear that Germany had embarked on a deliberate policy of expansion and hegemony which was inevitably leading to the destruction of the smaller countries. Further, Mussolini's attack on and annexation of Albania on 7 April 1939 caused great concern in Ankara and regarding the possible continuation of Italian expansion in the direction of the Turkish Straits. This last act led to closer Turkish co-operation with Britain and France.

The news that a lot of progress had been achieved in the Turco-British negotiations for the signature of a declaration of mutual co-operation and assistance in the Mediterranean and the Balkans stung the German Foreign Ministry into rapid action. Since the retirement of the last German ambassador to Turkey, Friedrich Von Keller, in November 1938, Berlin had been in no real hurry to fill this post. Since March 1938 Franz Von Papen had apparently been proposed three times as German ambassador in Ankara. Atatürk had turned his nomination down flat in April 1938, remembering him with distaste from the years of the First World War. Inönü had turned his name down again in November 1938 and in February 1939. And it was only when Saraçoğlu rashly demanded of Hans Kroll, German Chargé d'Affaires in Ankara, whether his government ever intended to fill the embassy, that Von Ribbentrop, who felt happier with Von Papen well away from Hitler's ear, returned, this time successfully, to 
the charge. When the conclusion of an agreement with Britain became apparent, President Inönü believed that "not even Von Papen could then make mischief in Turkey." The Turkish consent to his appointment, however, was given without enthusiasm ${ }^{55}$.

Troubled by the possibility of a Turco-Anglo-French rapprochement, Hitler had appointed the wily Von Papen ambassador to Turkey to cement German relations and strengthen the ties that were built on the very sizeable trade nourished by the clearing agreements of 1935. It was hoped in Berlin that Von Papen, a former staff officer in General Erich Von Falkenhayn's army in Syria and a man possessing much ability and good Turkish contacts, would be able to influence Turkey's policies. This was not the case, however, as the conclusion of the Turco-Anglo-French alliance subsequently proved ${ }^{56}$.

The imminent signature of the Turco-British declaration hurried Von Papen to Ankara. Nor was it only a matter of Turkey's relations with Britain. Turkey was in a very special position also with other countries such as the Soviet Union, Poland and Bulgaria. Here it could play a profoundly important part in reinforcing the anti-Axis front. Much to the anger and dismay of the European dictators Turkey was strong and was by no means to be frightened by bluff from whatever quarter. It needed no one to point out to it where its best interests lay.

Von Papen arrived on 27 April, and called on Saraçoğlu the same day. He found the conversation an upsetting experience. Von Papen asserted that Germany liked Turks and so long as Turkey was Germany's friend no one, especially Italy, could do anything against Turkey. Saraçoğlu, tough in mind and body, interrupted Von Papen to say that Turkey did not appreciate dependence on the friendship of others, and enquired whether the German ambassador meant that if Turkey was not on friendly terms with Germany, Italy would attack it? Von Papen excused himself and said

${ }^{55}$ British Documents on Foreign Policy - henceforth referred to as "B.D.F.P." -, ser. 3, vol. 5, no. 302, Knatchbull-Hugessen (Ankara) to Halifax, 27 April 1939. Massigli (1964), pp. 169 170. Massigli in ibid., p. 175 commented on Von Papen's appointment in the following words: "Germany has sent here as representative a man who, by his name and by his past, was most suitable to do disservice to the German cause. We could not hope for the better." Moreover, see Franz Von Papen, Memoirs, London, 1952, pp. 443 and 450-451.

${ }^{56}$ Ibid. 
he had expressed himself badly and had meant no such thing. Saraçoğlu went on to say that German ambassador could be sure of one thingTurkey was not afraid of the Italians. If they came along Turkey was certain of a happy conclusion. "They have their Italians and we have our Turks." Turkish government was worried by the occupation of Albania. Albania was a very poor country and Italian occupation would only prove expensive. Turkish government was therefore inclined to regard Albanian move as part of a concerted plan by the Axis powers and to consider that the time for Turkey had come to protect itself against surprises. Since then Turkey had been in contact with friendly countries and exchanges of views were in progress. Von Papen suggested an Italian declaration of friendship, only to hear Saraçoğlu retort that such a thing "would displease Turkey enormously". The Turkish Foreign Minister said that so long as Italy went on fortifying and reinforcing Dodecanese islands and since Italy had occupied Albania which was a vital point for Turkey, no verbal assurances would satisfy Ankara. Did Germany intend to proceed further in the Balkans. "Jamais de la vie," replied Papen. Then Germans can sleep quietly in their beds, replied Saraçoğlu. Von Papen retired, visibly disconcerted ${ }^{57}$.

British and French ambassadors in Ankara, Knatchbull-Hugessen and Massigli, and Saraçoğlu had all been rather impressed with the way Von Papen appeared to act as a spokesman for Italy, especially as the Italian ambassador, Ottavio de Peppo, had gone home leave a few days earlier remarking off-handedly that there was nothing for him to do in the Turkish capital. But in fact Von Papen had spoken on his own initiative. The suggestion for an Italian declaration was German ambassador's personal idea, and, having ascertained that it would offend Turkey's amour propre, he refrained from saying in his report he had made it but, nonetheless, urged that appropriate action be taken in Rome in the form of a conversation between Mussolini and the Turkish ambassador. All future Turkish decisions, he warned Berlin, depended on the attitude of Italy and an unequivocal statement by Mussolini. Berlin sent an edited

${ }^{57}$ F.O. 371/424/283. E3450/9/44. Knatchbull-Hugessen (Ankara) to Halifax, 28 April 1939. Documents Diplomatiques Français - henceforth referred to as "D.D.F." -, ser. 2, vol. 15, no. 511, Massigli (Ankara) to Bonnet, 28 April 1929. Hugh Knatchbull-Hugessen, Diplomat in Peace and War, London, 1949, p. 146. 
version of Von Papen's report to Hans Von Mackensen, the German ambassador in Rome, with the instructions that although "it was not believed in Berlin that a Mussolini statement will be sufficient" he should inform Count Galeazzo Ciano, the Italian Foreign Minister, fully of Turkey's new attitude and report his reactions. Mussolini reacted cynically to this gratuitous piece of advice. The Turks, he said, deserved to be attacked simply because they feared it. Ciano equally dismissed what he thought were Turkish importunities with the remark that after he had finished turning Albania into a bastion the complete dependence of the Balkans on the Axis would be assured ${ }^{58}$.

It was certain that the German government was going to use great efforts to establish influence in Ankara. Von Papen still had considerable weight as a diplomat. His diplomacy was a highly subjective thing based on a personal, even though fairly correct, assessment of the impetus behind Turkey's abandonment of neutrality and coloured, for a German diplomat of Great War vintage, by a not abnormal amount of Italophobia. However his reception in Ankara had not been warm. Indeed, it was hard to believe that the German government could have been so blind to its own interests as to insist, against the wishes of the Turkish government, on appointing an ambassador who was already so unfortunately remembered and so completely distrusted in Turkey.

Two days later he tried again, when presenting his credentials to President Inönü. Inönü was gentler with him, but equally frank. But his gentleness gave Von Papen the opening he needed. His report ${ }^{59}$ showed that he believed, or at least wished the German Foreign Minister to believe, that he was succeeding in choking off the issue of a Turco-British declaration. The Wilhelmstrasse, following the Turco-British negotiations through the decipherment of the Turkish diplomatic communications, remained unconvinced ${ }^{60}$. Von Papen's second meeting with Inönü on 2 May destroyed his own optimism. He found Inönü preoccupied by the

58 D.G.F.P., ser. D, vol. 6, no. 286 and fn. 8, Weizsacker to Mackensen (Rome), 28 April 1939. B.D.F.P., ser. 3, vol. 5, no. 302, Knatchbull-Hugessen (Ankara) to Halifax, 28 April 1939. D.G.F.P., ser. D, vol. 6, no. 303, Mackensen (Rome) to the Foreign Ministry, 1 May 1939. Ibid., no. 317, 5 May 1939.

${ }^{59}$ Ibid. Massigli (1964), p. 171.

${ }^{60}$ Ibid., no. 288, Papen (Ankara) to Foreign Ministry, 29 April 1939. 
threat from Italy, and wired Berlin urgently of the need to effect a reduction in the Italian troop concentrations in Albania ${ }^{61}$.

On 3 May, Ciano, to whom Von Papen's reports on his first meeting with Saraçoğlu and Inönü had been forwarded from Berlin ${ }^{62}$, spoke, halfreassuringly half-threateningly, to the Turkish ambassador in Rome, Hüseyin Ragıp Baydur ${ }^{63}$. As Von Papen was to discover over the next few days from both Inönü and Menemencioğlu ${ }^{64}$, this Italian gesture, being so obviously due to Von Papen's intervention, left the Turks unmoved. Saraçoğlu dismissed the assurances as worthless precisely because they had been extended at Germany's instigation ${ }^{65}$.

Von Papen remained convinced that the deterioration in the TurcoItalian relations was the crucial factor propelling Turkey towards Britain. Having failed to extract a formal statement from Rome, he now put forth three suggestions which he hoped would be discussed by Ciano and Ribbentrop at their forthcoming meeting in Milan. The first was that Italy should reduce its garrison in Albania and in southern Italy, then standing by his reckoning at 172.000 men with considerable artillery. The second was a plea for a reassuring statement of Germany's and Italy's attitude towards the Balkan Entente; and the third a suggestion that Albania and Bulgaria accede to the Entente, after a territorial concession from Romania, and that such an extended Balkan grouping be recognised by the Axis providing the member states, Turkey included, pledged unconditional neutrality. These suggestions-a hint of them was given to Menemencioğlu-were sent to Berlin with the request that they be submitted to the two foreign ministers while with the Turks Von Papen pleaded for a few day's grace, before the Turco-British Declaration of Mutual Assistance was announced ${ }^{66}$.

61 Ibid., no. 289, Circular of the Director of the Political Department, 29 April 1939. Ibid., no. 303 and fn. 6, Mackensen (Rome) to the Foreign Ministry, 1 May 1939. Ibid., no. 305, Circular of the State Secretary Weizsacker to the Embassies in London, Paris, Moscow, Ankara and Rome, 2 May 1939.

62 Ibid., no. 286, Weizsacker to Mackensen (Rome), 28 April 1939.

63 Ibid., no. 317, Mackensen (Rome) to the Foreign Ministry, 3 May 1939. Galeazzo Ciano, Diario: 1937-1943, Edited by Renzo de Felice, Milan, 1982, Entry for 3 May 1939.

64 Ibid., no. 324, Papen (Ankara) to the Foreign Ministry, 4 May 1939. Ibid., no. 333, Papen (Ankara) to the Foreign Ministry, 5 May 1939. Ciano (1982), Entries for 3, 4 and 5 May 1939.

${ }^{65}$ Massigli (1964), p. 172.

${ }^{66}$ D.G.F.P., ser. D, vol. 6, no. 333 and fn. 2, Papen (Ankara) to the Foreign Ministry, 5 May 1939. 
By late on 6 May Von Papen had to admit defeat for the news coming from Milan made no mention of his ingenious solutions. In fact, his telegrams had not even been forwarded to Ribbentrop, and it was not until 9 May that, with what appears to have been deliberate slowness, the German Under-Secretary of Foreign Affairs Ernst Von Weizsacker informed him that no information was yet available on the Ciano-Ribbentrop conversations. For good measure Weizsacker added that Von Papen should not create the impression that there existed any difference between Germany and Italy over the Balkans, that there was no question of Albania joining the Balkan Entente because it was now bound to Italy by personal union, that Berlin saw no reason to force Bulgaria into the Entente especially as there were no prospects of getting its territorial concessions and, finally, that Germany preferred to deal with the Balkan countries singly rather than in a bloc ${ }^{67}$.

It was an uncompromising rebuke whose importance went beyond the context within which it was delivered. It showed that the alliance with Italy had unquestioned priority and that, therefore, no Turkish recriminations would be allowed to jeopardise it by possibly setting off Ciano and Mussolini. It showed that, so far as the Balkans were concerned, Germany much preferred the existing state of rivalry to a homogenous unity even if the resulting block were Axis-dominated ${ }^{68}$. Von Papen was finally forced to confess his failure ${ }^{69}$.

The Turks had a great deal to set against Von Papen's arrival on the scene. From 1 to 5 May, Inönü, Saraçoğlu and the Chief of the General Staff, Marshal Fevzi Çakmak, had been entertaining the former French Chief of the General Staff, and Commander-in-Chief of France's armies in Syria, General Maxime Weygand at Ankara. This stroke of genius had been provoked by the French ambassador Massigli. The Turks made this visit into a major military occasion. Moreover, Inönü, who knew Weygand from the General's service on the French delegation to the Lausanne conference in 1923, felt able to speak with unusual ease. Germany, he said, had embarked on the path of universal domination. It had to be opposed. Britain and France were about to construct an Eastern Front in

${ }^{67}$ Ibid., no. 341, Unsigned Memorandum, 18 May 1939.

68 B.D.F.P., ser. 3, vol. 5, no. 414, Knatchbull-Hugessen (Ankara) to Halifax, 8 May 1939.

${ }^{69}$ D.G.F.P., ser. D, vol. 6, no. 336, Papen (Ankara) to Foreign Ministry, 6 May 1939. 
the Balkans. Turkey had chosen its side. "Your security is ours," he remarked Weygand. "We consider Germany the adversary," was the message from Ankara ${ }^{70}$.

Following their signing of the joint declaration with the British on 12 May, the Turks had had to face a great deal of German and Italian pressure. Axis powers' main line of approach to recent developments was to urge the Turkish government not to commit itself to a definite alliance with Britain and if it must do so to ensure that any such agreement contained a definition of the term "aggressor". They claimed that it was Britain which was preparing to provoke war. The Turkish government and people were, however, tough, resolute and determined not to be pushed around by either Hitler or Mussolini. In the Turkish view there was no change whatsoever, and friendly commercial dealings between Turkey and Germany were confidently expected to continue as before. The Mediterranean situation and threat to the Dardanelles inherent in the occupation of Albania had left Turkey no choice but to look round for allies in case of aggression. The joint declaration applied only to the case of an attack on Britain or Turkey in the Mediterranean. Out of consideration for friendship with Germany and in order not to make its position more difficult, Ankara had expressed itself very vaguely about possible attacks on the Balkans. The agreement was purely a defensive one and calculated to allay anxiety in the Mediterranean and thereby to contribute towards general peace. Ankara remained firm. Meanwhile the discovery that the Turco-British declaration was to be followed by negotiations for a treaty had awoken in Von Papen's ever-sanguine heart the thought that something might be done to abort these talks by reassuring Turkey on its apprehensions of Italy ${ }^{71}$.

The German ambassador took the opportunity of Ciano's visit to Berlin on 21 May for the signature of the Pact of Steel to put forth another proposal, slightly dissimilar from the one he had forwarded earlier in the

${ }^{70}$ D.D.F., ser. 2, vol. 16, no. 25, Report of General Weygand on his mission to Ankara, 3 May 1939. Ibid., no. 37, Massigli (Ankara) to Bonnet, 4 May 1939. Ibid., no. 39, Massigli (Ankara) to Bonnet, 4 May 1939. Ibid., no. 110, Massigli (Ankara) to Bonnet, 8 May 1939. Massigli (1964), pp. 283-286.

${ }^{71}$ D.G.F.P., ser. D, vol. 6, no. 374, Papen (Ankara) to the Foreign Ministry, 13 May 1939. B.D.F.P., ser. 3, vol. 5, no. 536, Knatchbull-Hugessen (Ankara) to Halifax, 18 May 1939. 
month, but whose core was essentially the same: only an Italian assurance could dissuade Turkey from continuing on its present course.

Von Papen, whose experiences fighting in Palestine in the First World War had taught him something of the strategic realities of the situation, was in no doubt regarding the significance of the agreement arrived at by Turkey and Britain. It meant, in a memorandum he laid before Ribbentrop, not only the loss of twenty years of German diplomatic investment in Turkey, but also a complete shift in the balance of power in the eastern Mediterranean. In a future war it might now be necessary for the Axis powers to seize Dardanelles, in order to exclude Britain from the Black Sea and Russia from the Mediterranean. With Albania as a bridgehead, however, such an operation might be accomplished with relative ease, by means of a 'rapid operation' mounted from Salonika. Not that the closure of Dardanelles would alone suffice to ensure the defeat of Britain. To secure that it would be necessary for Germany to hit Britain in its most vital point, in India. To do this, the Axis powers had to possess the "land bridge to India" (Syria, Palestine and "access to Mosul"). As such an operation could only be undertaken if Turkey were neutral, it was imperative that it be persuaded to abandon Britain. Otherwise, were it engaged, it might dig in with a 'very unfavourable military-political situation' from the outset. Turkish neutrality could, in his view, best be obtained by persuading Italy to reassure Turkey regarding its position in Europe, while at the same time 'disguising' the development of the position in Albania and opening negotiations with Turkey in respect to the islands of Castelrosso and Castelrizza (Meis), which lay within Turkey's three-mile zone ${ }^{72}$.

Von Papen duly returned to Berlin on 15 May to lobby for his new ideas, but found Ribbentrop and Hitler in a bellicose and uncomprising mood. Hitler had already arranged for the cancellation of a Turkish order for six heavy howitzers of the most modern type from the Skoda works, which were both ready for delivery and paid for. The bureaucrats in Berlin were prodded by Ribbentrop into discussing ways and means of exercising economic pressure on Turkey ${ }^{73}$.

\footnotetext{
72 Ibid., no. 413, Memorandum by Papen, 20 May 1939.

${ }^{73}$ Ibid., no. 321, Memorandum by Weizsacker, 3 May 1939. Papen (1953), pp. 448-449.
} 
On 24 May an inter-departmental meeting attended by representatives of the Wilhelmstrasse, the Ministries of Economics, Food and the FourYear Plan as well as the Reichsbank, the Air Force and the High Command of the Army was called to discuss what further action to take against Turkey. Von Papen's proposals were out of the question. The issue came down again to degrees of economic retaliation, with the representatives of the Ministry of Economics arguing stubbornly for the fulfilment of all existing contracts including those for heavy guns. But as Hitler had earlier pronounced against delivery, it now became a matter of deciding to what extent the supply of lighter materials could be delayed in view of Germany's need for chrome ore. The meeting decided not to fulfil orders on four $24 \mathrm{~cm}$. howitzers, while the Air Force and the High Command of the Army reserved a decision on whether ten aircraft and two submarine guns could be released. But, so as not to jeopardise chrome ore deliveries, it was decided to continue current transactions so far as possible, although not to enter into new ones, nor to extend the 25 July 1938 credit agreement. Von Papen was instructed to explain that nondelivery was due to political reasons and that it was hoped that Turkey would desist from advancing its claims in civil law under the delivery contracts already concluded so as not to exacerbate relations further ${ }^{74}$.

Back in Ankara by the beginning of June, Von Papen felt severely handicapped. Now precluded from conjuring further deals involving the Italians, he settled down to inducing Turkey to return to the paths of neutrality by withholding deliveries of armaments. Characteristically, he exceeded in diligence. His despatches painted a picture of himself bullying and dominating the cowering tongue-tied Turks ${ }^{75}$ One may take leave to doubt whether they represented the strict truth. For the usually well-informed Knatchbull-Hugessen reported on 7 June that the impression of the Turkish leaders was that, so far, German reaction to Turco-British negotiations were milder than they expected. Von Papen brought no proposal from Berlin but seemed to have confined himself to

74 Ibid., no. 435, Memorandum by Ripken (An official of the Economic Policy Department), 24 May 1939 and no. 454, Memorandum by Clodius, 30 May 1939.

75 Ibid., no. 475, Papen (Ankara) to the Foreign Ministry, 7 June 1939. Ibid., no. 512, Papen (Ankara) to Foreign Ministry, 12 June 1939. Ibid., no. 518, Papen (Ankara) to Foreign Ministry, 13 June 1939. 
warning Turkey that it was binding itself to the side which was preparing for war and to a vague hint that if the final Turco-British agreement appeared contrary to German interests Turco-German relations would suffer. As regards commercial relations German intention seemed to be to continue on the present footing until the conclusion of the final agreement when they would review the situation. According to the British ambassador, in reply to question by Saraçoğlu Von Papen seemed to have been reassuring even about war material with the exception of heavy guns. The latter nevertheless indicated the possibility of ultimate embargo on exports of munitions and enquired what Turkish government was then going to do as regards the export of chrome and cereals to Germany. Saraçoğlu pointed out to Von Papen that if Germany cut off the supply of munitions Turkey would be obliged to cease export to Germany of corresponding value of Turkish goods, otherwise balance would be heavily against Turkey ${ }^{76}$.

As Bernardo Attolico, the Italian ambassador in Berlin, who cordially disliked Von Papen, remarked to Von Weizsacker, speeches remained speeches and facts remained facts ${ }^{77}$. And the facts were that, despite Von Papen's oily charm, despite Ribbentrop's stormy interviews with the Turkish ambassador in Berlin, the stolid Arpag ${ }^{78}$, the Turco-French declaration made on 23 June had the identical text on the Balkans, Article 6, to which Grigore Gafencu, the Romanian Foreign Minister, and the Yugoslavs had made such extreme objections when it was originally included in the Turco-British declaration of 12 May. And the Turkish Prime Minister, Refik Saydam, in presenting the Turco-French declaration to the Grand National Assembly on the same day of its signature, delivered a eulogy of it which went even further than his comments on 12 May $^{79}$.

${ }^{76}$ B.D.F.P., ser. 3, vol. 5, no. 738, Knatchbull-Hugessen (Ankara) to Halifax, 7 June 1939.

77 Documenti Diplomatici Italiani, ser. 8, vol. 12, no. 227, Attolico (Berlin) to Ciano, 14 June 1939.

${ }^{78}$ D.D.F., ser. 2, vol. 16, no. 389, Coulondre (Berlin) to Bonnet, 10 June 1939.

${ }^{79}$ Ibid., no. 517. Text of the Turco-French Declaration of Mutual Assistance, 23 June 1939. Article 6 of the Turco-British and Turco-French Declarations of Mutual Assistance read as: "The two governments recognise that it is also necessary to ensure the establishment of security in the Balkans and they are consulting together with the object of achieving this purpose as speedily as possible." 
Ribbentrop first petulantly posted orders that no Turkish representatives be received in the Foreign Ministry, and then called in the Turkish ambassador for a severe dressing-down, adding instructions that the same brusqueness should be used in dealing with the principals in Ankara. The astute, tough and perceptive Arpağ-who disliked the Nazi leadership as much as, or more than, any of his colleagues in the Berlin diplomatic corps-replied firmly to Ribbentrop that the openly affirmed determination of Germany and Italy to acquire by conquest their 'vital living space' made it natural for Turkey, which had never staged a coup de force and had no aggressive designs, to range itself on the side of those powers which were defending peace ${ }^{80}$. And on $9 \mathrm{July}$, in a speech to the Turkish Grand National Assembly, Saraçoğlu remarked ironically that considering how strongly the basic text of the Nazi regime (Mein Kampf) recommended an alliance with Britain, it was difficult to understand why Turkey's choice of the same policy of friendship with Britain should be so condemned in the German press ${ }^{81}$.

The news of the Nazi-Soviet Pact caused the Turkish Foreign Minister, for the only time, to suffer a brief loss of nerve. On the morning of 23 August he was confronted with the news of Ribbentrop's dramatic descent on Moscow, and the realisation that the Soviets had been deceiving him for some time; he also saw as a major threat the German quasi-ultimatum of 21 August $^{82}$, proposing a cancellation of all extant arms contracts and of the credit agreement of January 1939, a prolongation of the 1938 agreements being made conditional on Turkish acceptance of this. "Distinctly upset", 83 he told Knatchbull-Hugessen that he could no longer resist to this pressure. For months he had been attempting to create a situation in which his country could withstand Germany; but he had not succeeded $^{84}$.

${ }^{80}$ Ibid., no. 389, Coulondre (Berlin) to Bonnet, 10 June 1939. D.G.F.P., ser. D, vol. 6, no. 496 and $\mathrm{fn}$. 12, Unsigned Memorandum on the conversation between Ribbentrop and the Turkish ambassador, 8 June 1939.

${ }_{81}$ Anatolian News Agency, 10 July 1939.

82 D.G.F.P., ser. D, vol. 7, no. 141 and fn. 6 thereto, Kroll (Ankara) to the Foreign Ministry, 21 August 1939.

${ }^{83}$ B.D.F.P., ser. 3, vol. 7, no. 188 and fn. 1, Knatchbull-Hugessen (Istanbul) to Halifax, 23 August 1939.

${ }^{84}$ Ibid., no. 161, Knatchbull-Hugessen (Istanbul) to Halifax, 23 August 1939. 
Saraçoğlu's failure of courage was only momentary. Later the same day, Massigli found him as resolute as ever. Turkey, Saraçoğlu said, had no intention of sitting down under German threats ${ }^{85}$. Two days later he told Von Papen Germany had broken all its promises. Turkey would not submit to German domination. All Turkish economic and technical missions in Germany would be withdrawn ${ }^{86}$. Inönü reinforced this two days later. Turkey, he told Von Papen, would act in accordance with its interests and commitments and would be found in any camp opposed to Germany. He went on and said that commercial matters played a subordinate role in questions of life and death. The Turkish President's attitude was adamant, and all the satisfaction the German ambassador was to derive from his interview was the statement that Turkey would honour its undertakings to Britain and France to aid them in resisting aggression. Papen, "thoroughly uneasy", was reported to have left the interview in a state of "acute perspiration". As well he should have Hitler, listening to General Wilhelm Keitel, Chief of the High Command of the German Army, had already reversed his decision on the German arms contracts. For this form of retaliation had its limits. Berlin was well aware that while Turkey might initially suffer more by the stoppage of trade, it could eventually find alternative export markets and suppliers. Germany, on the other hand, stood to lose more than 70 million marks in guarantees and payments outstanding and could not easily find an alternative supplier of chrome ore, indispensable to the munitions industry. "Germany might not need Turkish tobacco, but it needed Turkish chrome very badly"87.

Inönü and Saraçoğlu and the whole Turkish nation were not easy to bully or deceive. The German attack on Poland on 1 September added considerably to the tension. War had become a reality, and a false step by Turkish diplomacy might easily prove disastrous to the cause of national survival. The hallmark of Inönü's policy was realism and restraint. In this he was guided by the discerning and sophisticated Menemencioğlu-the brain and the driving force behind the Turkish diplomacy. Germany at

${ }^{85}$ Ibid., no. 188, Knatchbull-Hugessen (Istanbul) to Halifax, 23 August 1939.

${ }^{86}$ Ibid., no. 260, Knatchbull-Hugessen (Istanbul) to Halifax, 25 August 1939. D.G.F.P., ser. D, vol. 7, no. 247, Papen (Ankara) to the Foreign Ministry, 24 August 1939.

${ }^{87}$ Ibid., no. 370, Knatchbull-Hugessen (Istanbul) to Halifax, 27 August 1939. D.G.F.P., ser. D, vol. 7, no. 342, Papen (Ankara) to the Foreign Ministry, 27 August 1939. Ibid., no. 393, Papen (Ankara) to the Foreign Ministry, 28 August 1939. 
that time was primarily interested in keeping Britain and France from building a chain of encircling alliances in the Balkans and the Near East. It viewed with concern the guarantee that London and Paris on 12 April 1939 had given to Greece and Romania to defend their integrity and it sought to neutralise the Balkan countries and Turkey. Turkey held a key position, since Franco-British aid to Romania would have to pass through the Straits. To keep Turkey from co-operating with the West thus became one of the major objectives of German foreign policy at the beginning of the Second World War.

Strategic considerations arising from Britain's imperial position were vitally important in determining its policy towards Turkey. The worst which Britain envisaged and feared was that it would be involved in a war against Germany, Italy, and Japan at the same time. If such a war eventuated, support from Turkey would be most important to help protect Britain's freedom of passage through the Mediterranean and the Suez Canal, and its interests in the Middle East. However, it was believed that preparations for such support would further antagonise Italians and so risk provoking the very catastrophe which was most feared. Until 1939, the advice of military authorities was that Britain should conciliate Italy and strive to keep it neutral in any conflict. After the Italian invasion of Albania and its signature of the Pact of Steel with Germany, the British General Staff wavered, assumed that Italy would be hostile in any conflict, and, with the French, began to make preparations for a knock-out blow against what they thought would be the weaker enemy. In this climate, a joint guarantee with Turkey was signed on 12 May 1939. However, even before the Italian declaration of neutrality on the outbreak of war, Britain's strategy planners reverted to their previous stance and reimposed constraints upon the development of an alliance with Turkey. In addition, in the months leading up to the outbreak of war Turkey wanted material aid and serious preparations for war while Britain wanted the façade of an agreement as part of its policy of deterrence.

The development of Turco-British relations in the years between the two World Wars can be described as a gradual rapprochement. In 1918, the two countries were at war, and in 1939 they were bound by an alliance. This development, however, was not smooth. The Anglo-Italian and Turco-Italian conflicts in the Mediterranean region in the early 1930s 
facilitated and accelerated a closeness between Turkey and Britain which progressed with particularly quick strides after Mussolini's occupation of Ethiopia. Turco-British relations continued to develop steadily after the signature of the Montreux Straits Convention. In 1937 there was a strong desire in Turkish government to form an alliance with Britain. The Neville Chamberlain government of that year, however, politely refused a Turkish bid for alliance - although Britain attempted to counter German economic influence. The explanation of what amounted to the spurning of such Turkish moves was that the British Prime Minister was preoccupied elsewhere and Turkey's position did not rank high on his priority list.

Turco-British co-operation between 1934 and 1939, initially designed to help to restrain Italy in the Mediterranean, was a success partly because Turkey felt capable of meeting an Italian threat. However, when attention was redirected towards Germany, Turkey began to have doubts which were confirmed soon after it made an alliance with Britain and France in 1939. The economic relationship between Turkey and Britain never developed sufficiently to allow Ankara to view war with Germany as anything but an economic calamity. While Turkey could firmly reject the Italian claim to a dominant position in the eastern Mediterranean, it had to treat with attention a Germany whose share in Turkish exports rose from 13 to 43 percent between 1929 and 1938, and in Turkish imports from 15 to 47 percent during the same period.

Co-operation with Berlin, although resented by Ankara, was essential, even in the short-term, to the health of the Turkish economy. Opposition to Germany was unthinkable as long as Turkey could find an alternative supplier of vital military equipment. Turkey could not break with Germany if the result would be the disintegration, without a blow having been struck, of Turkey's economy and war-making ability. German imports were crucial to Turkey's ability to wage war. Germany had been a major supplier of raw materials for the armament factories built in the course of the incomplete second Turkish five-year plan of 1937, which aimed at selfsufficiency in weapons. German companies also built Turkey's strategic railways and were the prospective suppliers of most of the weapons for the long-planned, and incomplete, re-equipment of the Turkish army. As Germany accepted Turkish products in payment for its exports, Turkish producers depended upon German markets. 
Before Turkey could stand beside Britain against Germany, the Germans would have to be replaced as both suppliers and consumers; otherwise, Turkish factories would close, railroads would not run, and the army would face the prospect of fighting a new war with the weapons of the last, and without a reliable supply of ammunition. As British and French economic policies, until shortly before the Munich crisis, reinforced Germany's economic dominance, their alliance with Turkey was likely to be still-born. The Ribbentrop-Molotov pact and its menacing attitude helped to precipitate the Turks into the alliance but, even more than before, they clamoured for aid from their allies. Little was forthcoming.

Ever a martial nation, the achievements of the Turkish soldiers in the First World War were fresh in the memory. There was no doubt that the heroic defence of the Dardanelles added greatly to the length of the struggle. At the outbreak of the Second World War Turks were vastly more formidable than they were then, for the late Atatürk was supremely successful in his scheme for the development of a new Turkey-strong, independent, a menace to no one, but able to defend its interests most effectively if they were threatened. Already Turkey had declared its word; and it would be faithful to it to the end, no matter how bitter the path thither might be. The Turks, it was true, were not a volatile people and did not easily change their minds. However, Turkey's foreign policy was characterised by wisdom and caution. It experienced all kinds of foreign pressures and inducements but never gave in or compromised with the basic aim of its policy-to keep out of conflict and to preserve its independence and territorial integrity. 
